(c) CEDA/TU, 2015, US Library of Congress, Catalog Card No- : 79-915209, ISSN: 2091-0339

The Journal of Development and Administrative Studies (JODAS), Vol. 23(1-2), pp. 69-83

\title{
Tourism Development and Energy Consumption Pattern in Langtang Valley of Nepal Himalayas
}

\author{
- Prem Sagar Chapagain*
}

\begin{abstract}
Langtang is one of the three major trekking destinations in Nepal. Tourism development in Langtang was started since after the establishment of Langtang National Park in 1976. Langtang is the nearest mountain trekking route from Kathmandu. About 12000 tourists visit annually in Langtang Valley. The Langtang valley from Syabrubesi to Kyanjing has rich physical, biological and cultural diversity which has been the center of tourism activities in Langtang region. This paper aims to trace out the tourism development trend and energy consumption pattern by hotels and lodges of the region. There are three major tourist destinations i.e. Lamahotel, Langtang, and Kyanjing in the Langtang valley where there are 49 hotels altogether. Initially,by 2000, hotels were concentrated at Lamahotel, then to Langtang village and finally to Kyanjing. Many tourist hubs in mountain including the Langtang valley use firewood as a major source of energy. The per bed/day firewood consumption is slightly varied in different altitude in the valley. The amount of firewood consumption decreases with increasing altitude and the distance from the source of firewood collection places. The annual firewood consumption is the highest in Lamahotel that is 457 kilogram/bed followed by Langtang with 460 kilogram and Kyanjing $(400 \mathrm{~kg})$. It is important that the Bhattis consume more firewood. Hotels with less than 20 beds consume more firewood compared to big hotels suggests firewood energy threshold in the mountain tourism hub. LP gas and cow dung cake are other energy sources. The big hotels having more than 20 beds use more LG gas compared to smaller hotels.
\end{abstract}

Key-Words: Langtang valley, trekking, tourism, firewood, energy consumption, and energy threshold.

JEL Classification: $\mathrm{D}_{11}, \mathrm{D}_{14}, \mathrm{D}_{33}$ and $\mathrm{D}_{92}$

\footnotetext{
* Dr. Chapagain is Associate Professor at Central Department of Geography, Tribhuvan University. Corresponding Email: ps.chapagain@gmail.com
} 


\section{Introduction}

Nepal's bio-physical, socio-cultural diversity and scenic landscapes have been the means of attraction of tourists. It is the country ranges from about 60 meters to the top of the world, 8848 meters above sea level. Though, the country is small in terms of area, it has 125 social groups with their culture that spread over within the $147,181 \mathrm{sqkm}$ area. The country has three distinct but parallel geographical regions i.e. Mountain, Middle Hill, and Tarai arranged within about 200 kilometers' north-south distance. This geographical setting has resulted various types of climate and thereby an enormous bio-diversity. The snow covered mountain peaks, mountain ranges and various types of landforms have made Nepal a distinct place for diverse types of tourism such as adventure tourism, mountaineering and trekking, wildlife tourism to the religious pilgrimage.

Tourism has no longer history in Nepal. Nepal was just opened for foreigners after 1950. The systematic data of tourists is available only from 1962. There was 6179 tourists visited Nepal in 1962 that reached to 797,759 in 2013. Tourism activities have flourished in selected pocket areas in Nepal. In the case of Mountain region, though there are many pocket areas such as Kanchanjunga, Manaslu, upper Mustang, Dolpa, Humla but trekking and mountaineering activities have been concentrated in the Everest region in the east, Langtang region in the central and Annapurna region in the western Nepal. After Annapurna and Everest region, Langtang is the third major trekking destinations in Nepal. The Tourism activities in Langtang were started after the establishment of Langtang National Park in 1976. But there has been almost no research on tourism development trend in Langtang. Importantly, no researches have been found on energy consumption pattern by the hoteliers in Langtang.

Energy is the major driving force of development. Biomass accounts for 35 percent of primary energy consumption in developing countries (Balat \& Ayar, 2005; Demirbas et al., 2009). It is still the main energy source in a number of countries and regions e.g. Bhutan 86 percent, Asia 16 percent, East Sahelian Africa 81 percent and Africa 39 percent (Hoogwijk et al., 2005; Demirbas et al., 2009). Firewood is still a major source of energy in developing countries. In case of Nepal, firewood covers 77 percent of the total energy (WECS, 2010). Although firewood is very important source of energy, its reliable assessments on consumption, and supplies are limited in most part of the world (Arnold and Persson, 2003). Site-specific studies of fuelwood resource availability, growth, and consumption pattern are very essential for locally appropriate and sustainable forest management (Wangchuk, et al. 2014). Low income household become vulnerable with less availability of firewood as they cannot afford for other energy sources (Singh and Sundriyal, 2009). 
Studies on energy consumption pattern have mostly highlighted on household energy types, volume and factors determining the consumption amount in the Himalayas. Fox (1984) has pointed out family size, caste and season as important determinants for per capita household firewood consumption in mid hills of Nepal. In addition to these factors, food habit, land types and number of livestock also determine amount of firewood consumption in mid-hill region (Chapagain, 2011). While in tribal communities in India, small family uses less firewood compared to large families (Rawat, Vishvakarma, and Todaria, 2009).

There are very limited studies on energy consumption especially firewood consumption pattern from high altitude tourist destination. Energy consumption pattern of hotel and lodges is influenced by altitude, energy cost and availability of different energy sources. In addition to cooking at hotels, firewood is also used for heating, campfire in major tourist destinations in Nepal. The average daily firewood consumption is lower $(5.5 \mathrm{~kg} /$ tourist/day) in altitude below 2000 meters, it increases up to 3500 meters (upto $6.4 \mathrm{~kg} /$ tourist/day) and again decreases $(4.6 \mathrm{~kg} /$ tourist/day) above 3500 meters (Nepal, 2008). Garrett (2000) has studied in Makalu Barun conservation areas and found out more firewood consumption by tourist porters in buffer zone areas compared to inside the national park areas. In buffer zone firewood is easily available so that porters use firewood for cooking and heating. Other many studies have reported cow dung, kerosene as other alternative to firewood in high altitude and reported increasing amount of firewood consumption with increasing altitude approximately 20 percent more firewood consumption at 2000 meters and above altitude compared to below 1000 meter altitude (Bhatt, Negi and Todaria, 1994). While other many studies from Pamir, Garhwal Himalaya, Sikkim, Bhutan have similar findings (Bhatt and Sachan,2004; Förster et al, 2011; Wangchuk, et al. 2014; Mislimshoeva, 2014).

Similarly, Demurger and Fournier (2010) have mentioned various factors determining firewood consumption pattern in rural China. According to them income, particularly households' income, households' total expenditures, or a measure of households' wealth or assets, are key factors in explaining energy use behavior. There is an inverse relationship between wealth and firewood. The other factors such as household size, the household average age, the average education level of adult members, and the nonagricultural labor force in the household also affect firewood consumption. The income or assets as measures of wealth, according to them, can be measured based on farmland, livestock, wealth index, and dwelling size. Baland et. al (2007) have focused on the linkage between poverty and forest degradation and concluded that firewood consumption decreases with increasing income as people can invest to other sources of energy. But, it remains the question of availability of those sources. 
The "energy ladder" hypothesis argues that households switch their fuel use from biomass to modern energy sources if there is increase in their income. It says that firewood is the inferior type of energy that is replaced by superior types such as bio-gas, LP gas and electricity (Arnold, Köhlin, \& Persson, 2006) with increasing level of income.

In this context, the available literature has mostly dealt on household firewood consumption pattern from lower altitude. Literature also suggests that firewood consumption amount increases with increasing altitude. But it has not discovered that at what extend firewood consumption increases and what other factors especially in the case of lodges and hotels determine the firewood consumption amount is still unknown. In this context, this paper first discusses the tourism development trend in the Langtang Valley and explores the nature and extends of utilization of different types of energy by hoteliers. Importantly, this paper aims to answer two questions that i) how much firewood is used by hotels of different capacity in the different altitude, and ii) is there any threshold amount of firewood utilization beyond which hoteliers change energy types. These issues are very pertinent in the context of increasing tourist flow in the mountain areas where there are limited forest resources and local people and hoteliers mainly depend on firewood for energy.

\section{Methods and Materials}

The Langtang Region lies in the Himalaya just at the north east of the Kathmandu. The region has declared Langtang National park (LNP) in 1976 that cover $2130 \mathrm{sqkm}$ area (ICIMOD, 1988).The LNP borders with Tibetan Autonomous Region of China in the north and east, the Trisuli /Bhotekoshi River in the west and Bhotekoshi/Sunkoshi River in the south. The LNP ranges from $1000 \mathrm{~m}$ elevation to Langtang Lirung Peak of $7245 \mathrm{~m}$ above sea level. The national park covers parts of Rasuwa District (56\%), Sindhupalchok district (38\%) and Nuwakot District (6\%). There are three main regions in LNP. These are 1) Langtang Valley 2) Helambu and 3) Gosaikunda Lake regions.

The Langtang valley lies in the north western part of the LNP. There are three major settlements such as Lamahotel located at $2500 \mathrm{~m}$, Langtang at 3400 , and Kyanjing at 3850 meter elevation. The valley is extended from Syafrubesi, $2000 \mathrm{~m}$ to Langtang Lirung $7345 \mathrm{~m}$.

The Langtang Valley is one of the major parts of the LNP that is selected for the study (Figure 1). Bamboo is located next to Syafrubesi. It is a beautiful place before ascending to Lamahotel. The valley consists Langshisha glacier, Kyanjing, Langtang Himal and other mountain peaks and glaciers. The valley is the main destination of trekkers in the LNP. It is famous for the endangered wildlife such as Red Panda, Musk deer, Himalayan Thar, Wild-boar etc. 


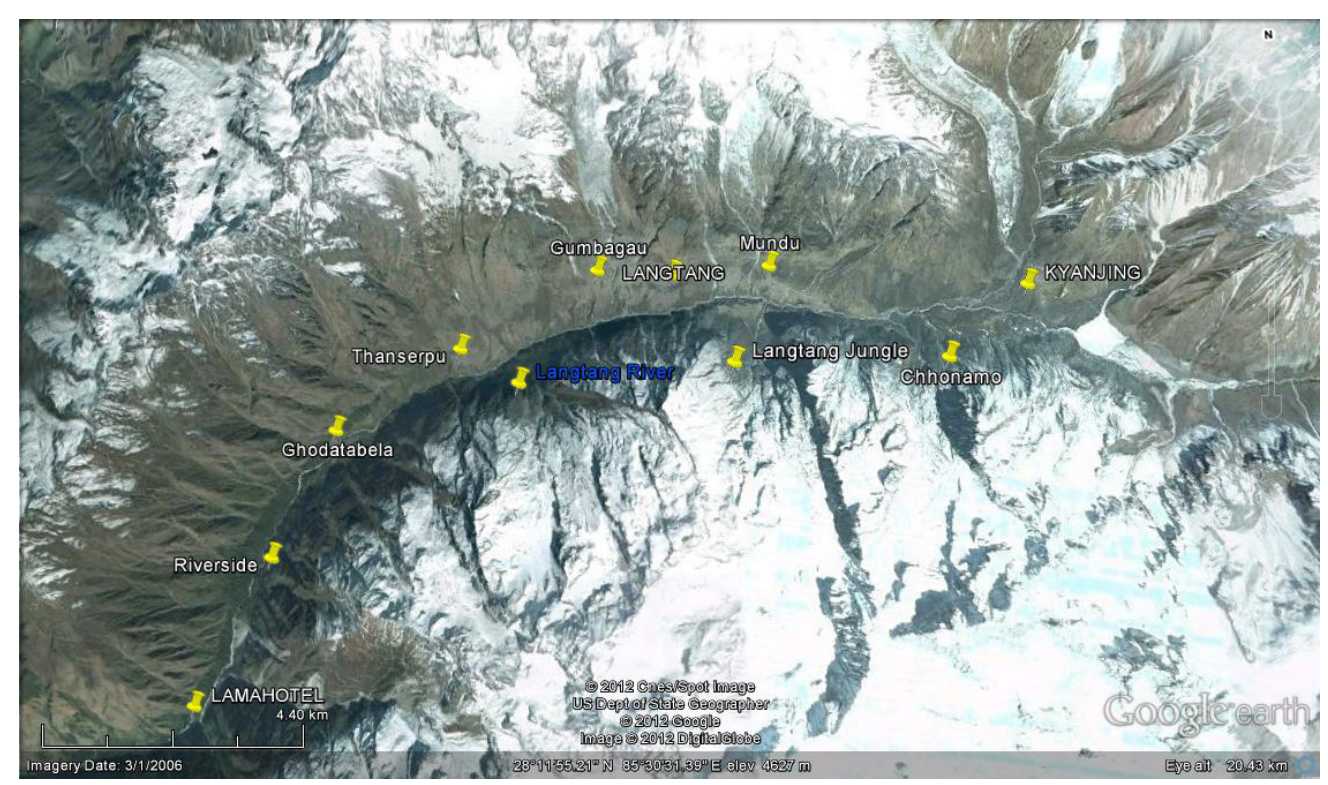

Figure 1: The Langtang Valley

The temperature of the valley is very seasonal. The mean annual temperature is about $13.6^{\circ} \mathrm{C}$. Winter temperature is very cold and characterized by cold nights, usually near freezing, and days that are generally clear and mild. Snow occurs from November to May. Out of total rainfall, $76 \%$ of the $1374 \mathrm{~mm}$ annual precipitation occurred during the monsoon (Sayers, K. and Norconk, 2008). The average air temperature of the highest settlement, Kyanjing, goes minus from November to February. The maximum temperature goes up to 15 degree Celsius in early August. The minimum temperature remains to minus 9 degree in December (McVeigh, 2004).

Tamang and Bhotias are the major settlers. Most of the hotel owners are the local people. The average household size is five. Out of total population, 55 percent are male and remaining 45 percent are female. Literacy rate is low. Thirty percent people are illiterate. Their livelihood is based on tourism, agriculture and livestock. About 80 percent economically active family members involve in tourism activities and remaining are engaged in agriculture, livestock rearing and service sectors.

The study is based upon both quantitative and qualitative datas collected through various methods and techniques. Primary datas are collected from hotel owner using questionnaires, Key informant interview, and observation methods in April and May 2012. Out of total hotels, 21 hotels, lodges and restaurants are surveyed for the detail study. 5 hotels are taken from Lamahotel (including 1 from Ghodatabala), 8 from Langtang and 8 from Kyanjing. It comes 
about 40 percent of the total such establishment of the respective settlements. The sample hotels are selected based on the discussion with local key informants so that they represent all types and sizes of the hotels and restaurants. They are selected after preparing the hotel inventory at each location. The collected data are tabulated and analyzed using SPSS.

\section{Tourism Development in Langtang Valley}

\subsection{Number of tourists to Nepal and Langtang Valley}

Langtang valley is the closest mountain trekking destination from to Kathmandu. The Langtang valley starts from Sybrubesi. On can reach there by one day bus/car drive. Trekking starts from Sybrubesi. It usually takes one day to reach Lamahotel, the next day to Langtang and the third day to Kyanjing. While returning back, two days are enough to walk down to sybrubesi. The tourism related activities in Langtang have been started since after the establishment of the Langtang National Park in 1976. It has got its momentum after 1980 (ICIMOD, 1999).

Tourist arrival in Nepal has increased from 162 thousands to 800 thousands from 1980 to 2013. Trekking tourism has also increased over the time. Although the total number of tourists and trekkers has been decreased after 2000 due to the internal conflict, it has been again substantially increased after 2010. The total number of tourists to Nepal and the total numbers of trekkers in Langtang region is given in Table 1. Trekkers to Langtang have been increased form 4113 in 1980 to 12649 in 2012 . These all trekkers do not trek to Langtang valley. In the absence of official recording, it is not exactly known that how many tourists visit to Langtang valley but it claims that more than one third tourists of the region trek to Langtang Valley especially in March-April and September- October seasons.

Table 1: Tourist to Langtang national Park

\begin{tabular}{|r|r|r|r|r|}
\hline Year & $\begin{array}{c}\text { Total tourist } \\
\text { to Nepal }\end{array}$ & $\begin{array}{r}\text { Total trekkers in } \\
\text { Nepal }\end{array}$ & $\begin{array}{c}\text { Trekkers in Helambu- } \\
\text { Langtang }\end{array}$ & \% to total trekkers \\
\hline 1980 & 162,897 & 27460 & 4113 & 15.0 \\
\hline 1990 & 254,885 & 61472 & 7826 & 12.7 \\
\hline 2000 & 463,646 & 118414 & 10917 & 9.2 \\
\hline 2005 & 375,398 & 61488 & 2735 & 4.4 \\
\hline 2010 & 602,867 & 70218 & $10315+$ & 15.1 \\
\hline 2011 & 736,215 & 261,987 & $13838+$ & \\
\hline 2012 & 803,092 & 313,126 & $12649+$ & \\
\hline 2013 & 797,759 & $\mathrm{NA}$ & $\mathrm{NA}$ & \\
\hline
\end{tabular}

Source: MCTCA, 2010, 2012. + Foreigners visiting to LNP recorded as per the Nepali calendar year that starts from July 16. NA stands for data not available. 


\subsection{Establishment of hotels and Lodges in the Langtang valley}

With increasing number of tourists, tourism activities have also increased in the valley. The numbers of hotels, lodges and restaurants have rapidly increased in all the three major villages.

It is important to mention that permanent types of touristic infrastructures such as hotel and lodges have come in the villages where a day trek ends and tourist stay there before starting to trek to the next village. Tourists start from Kathmandu in the morning and reach to Syafrubesi by bus in the evening. The next day, trekking starts from Syafrubesi and ends at Lamahotel via Bamboo. From Lamahotel, they reach to Langtang Village. Langtang is the major settlement and it is also the oldest settlement of the valley. From Langtang village, tourists take one day's trek to Kyanjing, the uppermost village of the valley. It is because of the distance, the major tourist destinations have developed in those three villages of the valley.

By 2012, 49 hotels and lodges have been established in the valley. Out of them the largest numbers of hotels and lodges are in Kyanjing(20) followed by Langtang (17) and Lamahotel (12). Before 1990, there were 10 hotels and lodges in the valley and these were mainly confined in Lamahotel. In the period between 2000-2005, 13 such establishments appeared and about 70 percent of those were established in Kyanjing. In the period 2005 - 2010, 14 hotels were established and most of them were established in Langtang. (Table 2, Figure 2).

Table 2: Establishment of hotel and lodges in the Langtang valley

\begin{tabular}{|l|r|r|r|r|r|r|}
\hline Village & $\begin{array}{r}\text { Before } \\
1990\end{array}$ & 1990-'00 & 2000-'05 & 2005-'10 & After 2010 & Total \\
\hline Lamahotel & 6 & 4 & 1 & & 1 & 12 \\
\hline Langtang & 1 & 1 & 3 & 9 & 3 & 17 \\
\hline Kyanjing & 3 & 3 & 9 & 5 & & 20 \\
\hline Total & 10 & 8 & 13 & 14 & 4 & 49 \\
\hline$\%$ & 20.4 & 16.3 & 26.5 & 28.6 & 8.2 & 100.0 \\
\hline
\end{tabular}

Source: Field Survey, 2012.

In the beginning, hotels and lodges were concentrated in Lamahotel. But after 2000 such infrastructures have rapidly come in Kyanjing and Langtang. 
Figure 2: Number of hotels established in different period in the Valley

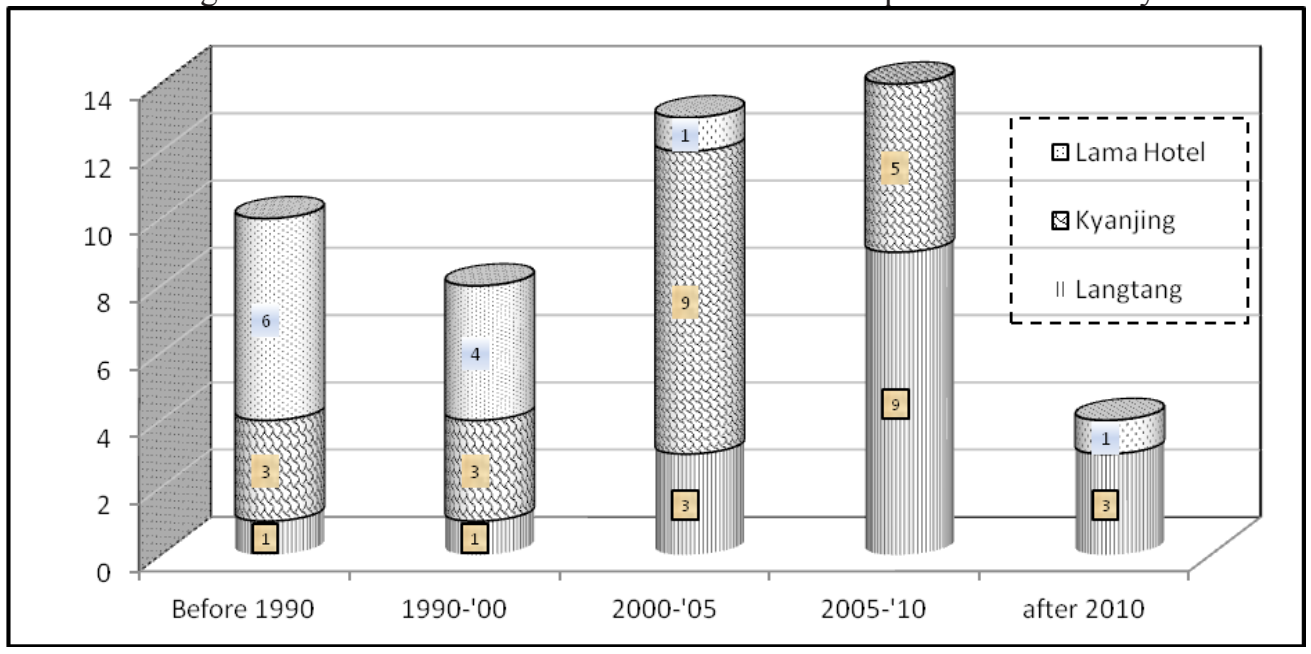

Out of total surveyed hotels, lodges and restaurants; the bed number ranges from 0 to 32 . There are a few restaurants offer services to tourist but they do not have bed. Such (zero bed) restaurants are in all villages. There are five hotels with 18 beds in each one followed by 3 hotels with 12 beds, 2 hotels with 24 beds and one each having 26 and 32 beds. Majority of the hotels, about 80 percent, have more than 10 beds (Table3).

Table 3: Number of hotels by size (bed number)

\begin{tabular}{|c|c|c|c|c|}
\hline \multirow{2}{*}{ Number of Bed } & \multicolumn{4}{|c|}{ Number of hotel by village and size } \\
\hline & Lamahotel & Langtang & Kyanjing & Total \\
\hline 0 & 1 & 2 & & 3 \\
\hline 6 & & & 1 & 1 \\
\hline 8 & & & 1 & 1 \\
\hline 10 & & & 1 & 1 \\
\hline 12 & 2 & & 1 & 3 \\
\hline 16 & & 2 & & 2 \\
\hline 18 & & 3 & 2 & 5 \\
\hline 21 & & 1 & & 1 \\
\hline 24 & 1 & & 1 & 2 \\
\hline 26 & 1 & & & 1 \\
\hline 32 & & & 1 & 1 \\
\hline Total & 5 & 8 & 8 & 21 \\
\hline
\end{tabular}

Source: Field Survey, 2012. 
Not only the total number of hotels but also the total number of beds have increased in all the three villages. There are 660 beds available in the three villages of the valley. The trend of increments of beds has been found very rapid from 1990 to 2010. By 1990, there were 204 beds in all the hotels and lodges of the three villages that increased to 310 by 2000,461 by 2005, 636 by 2010 and 660 by 2012. As given in Figure 4, there were 204 beds before 1990 that was increased to 660 by 2012 May. By 1990, 50 percent of the total beds of the valley were in the Lamahotel and remaining 50 percent were in other two villages. This trend of concentrating hotels and beds at Lamahotel was further continued up to 2000.

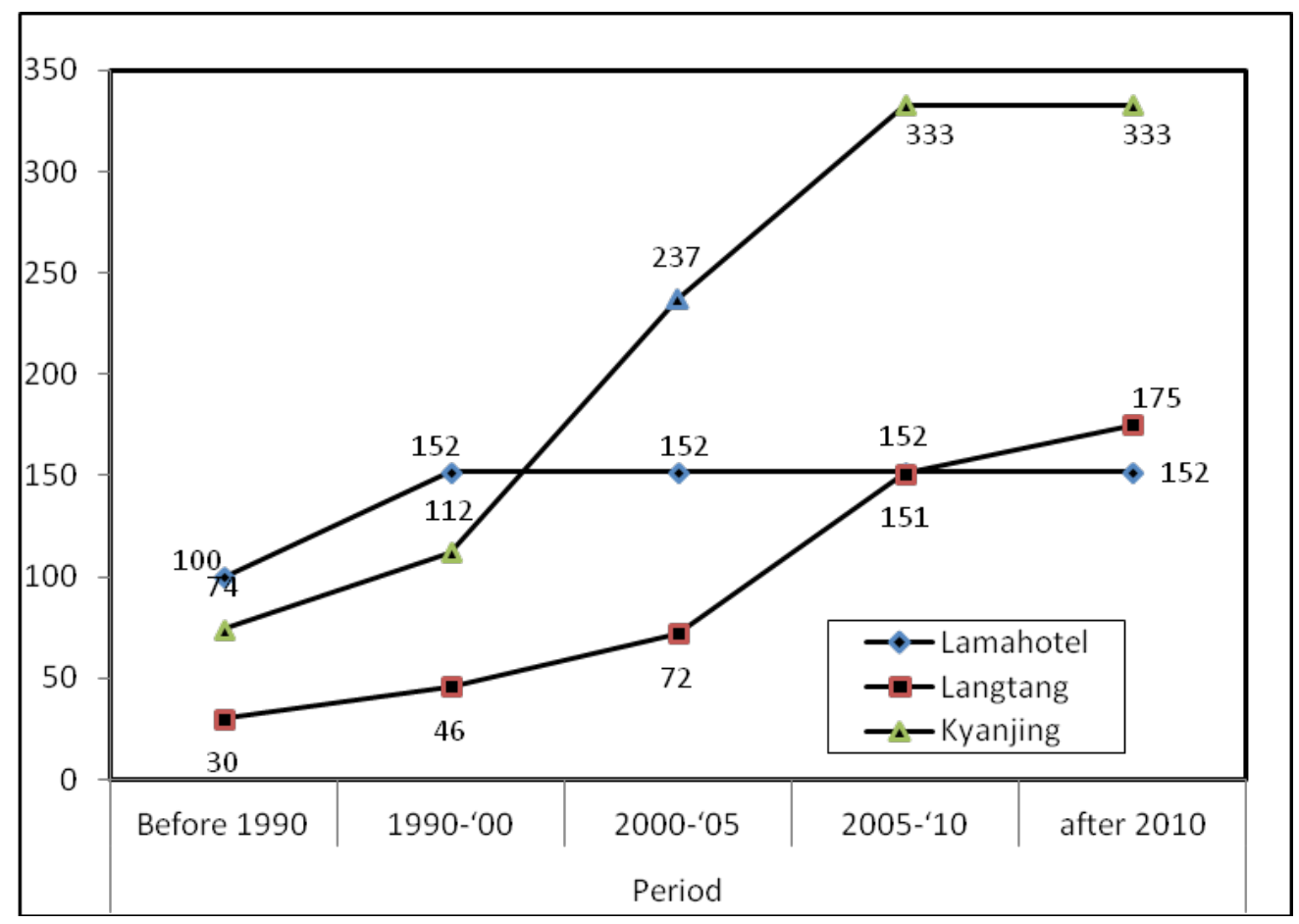

Figure 3: Cumulative numbers of beds by settlement and time period

However, the scenario of hotel establishment and availability of beds in villages was changed after 2000. Out of total added beds (151) in the period of 2000-2005, 125 were added in Kyanjing village alone. The similar trend was continued from 2005-2010 that out of total new added beds (175), 96 were added in Kyanjing and 79 in Langtang village. After 2010, scenario has little changed that 75 percent of new hotels established in Langtang and no new hotels established in Kyanjing. 


\subsection{Firewood Consumption Pattern}

Hotels use different types of energy such as firewood, LP gas, cow dung cake, kerosene oil for cooking, heating and lighting purposes in Langtang valley. Although there are different energy sources, firewood is still the major source of energy of hotels in the Valley. Firewood is mainly used for cooking, heating and camping. The average annual firewood consumption is 6229 kilogram per hotel. Average consumption by village per hotel is varied. It is $6760 \mathrm{~kg}$ in Lamahotel and $5950 \mathrm{~kg}$ in Kyanjing, and $6175 \mathrm{~kg}$ per year in Langtang (Table 4).

Table 4: Annual firewood consumption by village

\begin{tabular}{|l|r|l|l|l|}
\hline \multirow{2}{*}{ Settlemet } & \multicolumn{5}{|l|}{ Annual Firewood consumption (bhari) by village } \\
\cline { 2 - 5 } & $\begin{array}{l}\text { Total } \\
\text { Hotel }\end{array}$ & $\begin{array}{l}\text { Total Firewood } \\
\text { (Bhari) }\end{array}$ & $\begin{array}{l}\text { Averge Firewood } \\
\text { (Bhari)/Hotel }\end{array}$ & $\begin{array}{l}\text { Average/ hotel (in } \\
\text { Kg) }\end{array}$ \\
\hline Lamahotel & 5 & 845 & 169.0 & 6760 \\
\hline Langtang & 8 & 1235 & 154.4 & 6175 \\
\hline Kyanjing & 8 & 1190 & 148.8 & 5950 \\
\hline Total & 21 & 3270 & 155.7 & 6229 \\
\hline
\end{tabular}

Note: One bhari is considered 40 kilogram.

The average quantity of firewood consumption is higher in Lamahotel and lower in Kyanjing. The higher amount of consumption in Lamahotel is due to the short distance to the firewood collection places and easy availability of firewood compared to other two villages. As Lamahotel is located in lower altitude i.e. 2500 meters and there are good forest around the village.

Not only the distance and availability, the size of hotel has also related to the quantity of firewood consumption. It is found that restaurants and bhattis without having lodging facilities to tourists use higher amount of firewood. The hotels having less than 10 beds consume 160 bhari firewood per year. Similarly, 10-14 beds hotels consume 170 bhari firewood, 15-19 beds hotels use 145 bhari and hotels with 19-24 beds consume 110 bhari firewood annually in Kyanjing (Table 5).

Table 5: Firewood consumption by hotel size and village

\begin{tabular}{|l|r|r|r|r|r|r|}
\hline \multirow{2}{*}{ Settlement } & \multicolumn{5}{|c|}{ Firewood consumption (in Bhari) by number of beds in Hotel } \\
\cline { 2 - 7 } & 0 bed & $<10$ & 10 to 14 & $15-19$ & $19-24$ & $25+$ \\
\hline Lamahotel & 170 & & 140 & & 160 & 165 \\
\hline Langtang & 150 & & & 160 & 140 & \\
\hline Kyanjing & & 160 & 170 & 145 & 110 & 130 \\
\hline
\end{tabular}


It is clearly found that firewood consumption is higher in restaurants and bhattis. They serve food, snakes, prepare local alcohol (raksi) and serve directly to tourists and trekking guide, porters. Importantly, they supply local liquor to hotels and lodges. These local restaurants and bhattis are relatively cheap, and also provide fresh food and snacks. These are the places of socialization, entertainment to tourist guide and porters. Thus, it is obvious that they consume more firewood. It is also found that hotels and lodges of smaller size i.e. having less than 15 beds use more firewood compared to the hotels having more than 15 beds. So big hotels use less firewood compared to small hotels.

It is interesting and also important to know the average firewood consumption per bed per year and to estimate the total amount of firewood that the hoteliers consume annually in the valley. The average firewood per bed is lower in Kyanjing compared to other two villages i.e. Lamahotel and Langtang. Annually, it consumes $400 \mathrm{~kg}$ firewood in Kyanjing, $456 \mathrm{~kg}$ in Lamahotel and $461 \mathrm{~kg}$ in Langtang (Table 4.7).

Table 6: Average annual firewood consumption per bed

\begin{tabular}{|l|r|r|r|}
\hline Villages & Lamahotel & Langtang & \multicolumn{1}{c|}{ Kyanjing } \\
\hline Total sample hotel & 5 & 8 & 8 \\
\hline Total bed of sample hotel & 74 & 107 & 119 \\
\hline Total bhari & 845 & 1235 & 1190 \\
\hline Bhari per bed & 11.4 & 11,5 & 10 \\
\hline Kg /bed/year & 456.8 & 461.7 & 400 \\
\hline Total number of available beds & 152 & 175 & 333 \\
\hline
\end{tabular}

\subsection{Alternative Energy Types and Consumption}

Besides firewood, LP gas, cow dung cake (guitha) and kerosene are used for the purpose of cooking and heating in the valley. Among them LP gas is very important.

LP gas has been started to be used by a few hotels for the last five years and almost all hotels have started for two years in the valley. It is carried all the way to the village by horse and mule from Syafrubesi. The transportation cost is nearly equal to its price in Lamahotel and it increases to further villages. Its price is about 3200-3500 in Langtang and 4000 per cylinder in Kyanjing. Among the three villages, the average number of LPG cylinder per hotel is higher in Lamahotel and lowest in Langtang. It is used 10.5 cylinders per hotel in Kyanjing. 
Hoteliers take decision of using LPG and firewood based on price and availability. LP gas is relatively cheaper in Lamahotel because of shorter distance from Syafrubesi compared to Langtang and Kyanjing. Although, firewood is available in an abundance but labor cost for collection is higher i.e. NRs500/day and food so they also gradually switch to LP gas. In an average, one labor collects two to three bhari of firewood per day. Firewood is least available in Kyanjing but it is still essential for heating at hotel so they paid much, up to 700 , for a day labor. In a day, one labor collects hardly two bharis or about 80 kilograms. It is found a sort of threshold that the hotels with more than 15-20 beds use more LP gas compared to small hotels (Table 7).

Table 7: Number of LPG by hotel size (bed number)

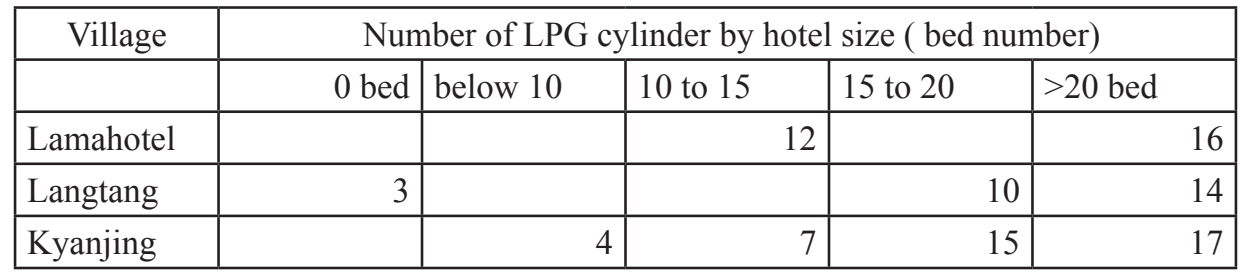

Cow dung cake (guitha) is another source of energy. It is used for cooking and heating. Local people use firewood and guitha together while cooking. People claim that guitha give more energy and helps in burning firewood. While using it for heating, they put guitha in heater that gives heat for 2-3 hours. People collect guitha from highland pasture (kharka) where chauri and yak graze. Specially women collect dung as it is found in kharka and they bring it to the village and make guitha. No hoteliers collect and use guitha in Lamahotel. Only 14 percent in Langtang and 33 percent hotel in Kyanjing use guitha. The average quantity of guitha consumption is 450 kilogram per year in Langtang and 589 kilogram in Kyanjing.

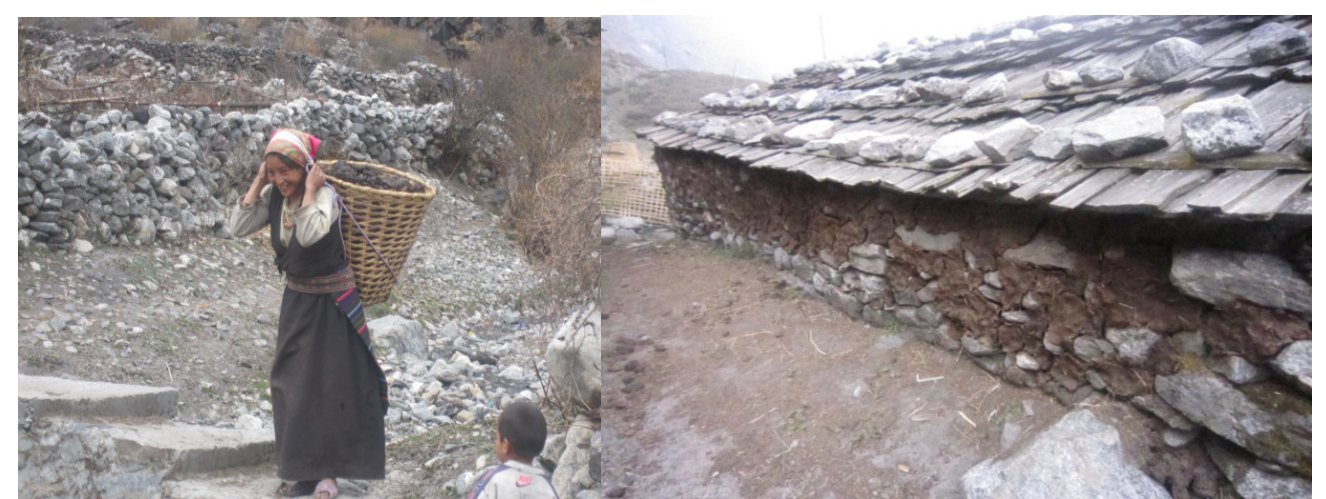

Figure 4: Women carrying guitha in Langtang

Figure 5: Cow dung pasted on wall to make cow dung cake 
Guitha has a few comparative advantages that i) it is free of cost that can be collected freely from kharka, ii) good source of energy, iii) compared to firewood collection cost it is cheaper and also iv) easy to collect as household members collect while visiting to livestock at kharka. Kerosene is limitedly used in Lamahotel and Kyanjing. It is used for cooking in Lamahotel and for lighting in Kyanjing.

\section{Concluding Remarks}

Energy is the basic need and the driving force of development. In rural areas including trekking destinations in Nepal, firewood is still the major source of cooking and heating. Langtang valley is the third major trekking destinations in Nepal. About 12,000 trekkers visit annually in Langtang Valley. With increasing number of tourists; the number of hotels, lodges and restaurants have also increased from 10 to 49 from 1990 to 2012 having the record of highest numbers of such establishments between 2000-2005 and 2005-2010 i.e. 13 and 14 respectively. In terms of the village, there are 12 hotels, lodges and restaurants in Lamahotel followed by 17 in Langtang and 20 in Kyanjing. Importantly, out of total 660 beds available in the valley, 152 are in Lamahotel, 175 in Langtang and 333 in Kyanjing.

Firewood has been the major source of cooking and heating for the rural people in mountain communities since long back. It was same for the hoteliers until around 2005 in Langtang valley. Firewood is still the major source of energy in hotels followed by LP gas, guitha and kerosene oil. In an average, a hotel consumes 156 bhari (one bhari $=40 \mathrm{~kg}$ ) of firewood annually in Langtang valley. This figure is much higher (169 bhari) than the average in Lamahotel where forest is very close and firewood is abundantly available. Annual per bed firewood consumption is 11.4 bhariin Lamahotel,11.5 bhari (462kg) Langtang, and 10 bhari (400kg) in Kyanjing. Many studies find that firewood consumption increases with increasing altitude (Bhatt and Sachan, 2004; Förster et al, 2011; Wangchuk et al. 2014; Mislimshoeva, 2014) but it does not apply in this case as beyond certain altitude there is no availability of firewood such as in the case of Langtang and Kyanjing Village. Both physical distance and per unit cost of firewood have been major factors in determining the consumption amount rather than the altitude. Importantly, there is also a threshold in firewood consumption. It is found that when hotel increases its bed capacity it can afford for higher quality of energy i.e. LP gas. In this study, small hotels with less than 20 beds consume more firewood than the big hotels with more than 20 beds. However, exception is the restaurants and bhattis. These restaurants and bhattis are the center of attraction for budget tourists and associated staffs who visit for food, snacks and drinks. Such establishments in tourist destinations prepare local liquor such as $j a d$, raksi for themselves and for tourist hotels and provide fresh food and beverage in relatively cheap price. Importantly, such places are the place of entertainments and socialization in the evening.

LP gas is the second most important energy source of hoteliers that has almost been used by all hotels for last two years. In an average $11 \mathrm{LP}$ gas cylinders per hotel per year is used in Lamahotel followed by 10.5 cylinders in Kyanjing and 8.5 cylinders in Langtang. The least 
number of LP gas has been consumed by restaurants and bhattis and by hotels having less than 15-20 beds. Hotels having 20 and above beds have used more LP gas cylinders in all villages. It shows a short of energy transition and also justifies their less amount of firewood consumption. Guitha (cow dung cake) is used by 14 percent hotel in Langtang and 33 percent hotel in Kyanjing. The average quantity of guitha consumption is 450 kilogram per year in Langtang and 589 kilogram in Kyanjing. Its consumption increases with increasing altitude.

\section{References}

Arnold, M., and Persson, R. (2003). Reassessing the fuelwood situation in developing countries. International Forestry Review, 5, pp. 379-383.

Balat, M., \& Ayar, G. (2005). Biomass energy in the world:Use of biomass and potential trend. Energy Sources, 27, pp. 931-940.

Bhatt, B.P., and Sachan, M.S. (2004). Firewood consumption along an altitudinal gradient in mountain villages of India. Biomass and Bioenergy, 27(1), pp. 69-75

Bhatt, B.P., Negi, A.K., and Todaria, N.P. (1994). Fuel wood consumption pattern at different altitudes in Garhwal Himalaya. Energy, 19(4), pp. 465-8.

Chapagain, P. S. (2011). Energy consumption pattern. In P. K. Pradhan (Ed.). Environmental Resources and Cultural Lnadscape: Understanding Changing Spatial Organization of Bhimeshwor, Dolakha (pp. 55-76). Kathmandu: Central Department of Geography, Tribhuvan University.

Demirbas, M. F., Balat, M., \& Balat. H. (2009). Potential contribution of biomass to the sustainable energy development. Energy Conversion and Management, 50, pp. 17461760.

Förster, H. Pachova, N.I., and Renaud, F.G. (2011). Energy and land use in the Pamir-Alai Mountains. Mountain Research and Development, 31(4), pp. 305-314.

Fox, J. (1984). Firewood consumption in a Nepali village. Environmental Management, 8, pp. 243-250.

Garrett, B.H. (2000). Dhokos and Dauri: Tourism related firewood use in the Makalu-Barun Area, Nepal. Environmental Sciences Program, University of California at Berkeley ( accessed on October 24, 2015)

Hoogwijka, M. et al. (2005). Potential of biomass energy out to 2100, for four IPCC SRES land-use scenarios. Biomass and Bioenergy, 29 (4), pp. 225-257.

ICIMOD.(1999). Energy use in mountain areas: Trend and pattern in China, India, Nepal and Pakistan. Kathmandu: ICIMOD.

McVeich, C. (2004). Himalayan herding is alive and well: The economics of pastoralism in the Langtang valley. Nomadic Peoples Ns, 8 (2), pp. 107-124. 
Ministry of Culture, Tourism \& Civil Aviation (2011). Nepal Tourism Statistics 2010. Kathmandu: Ministry of Culture, Tourism \& Civil Aviation, GoN.

Ministry of Culture, Tourism \& Civil Aviation (2013). Nepal Tourism Statistics 2012. Kathmandu: Ministry of Culture, Tourism \& Civil Aviation, GoN.

Mislimshoeva, B. et al. (2014). Factors influencing households' firewood consumption in Western Pamir, Tajikistan. Mountain Research and Development, 34(2), pp. 147156. DoI.

Nepal, S. K. (2008). Tourism-induced rural energy consumption in the Annapurna region of Nepal Tourism Management, 29(1), pp. 89-100. DOI: 10.1016/j.tourman. 2007.03.024.

Rawat, Y.S.; Vishvakarma, S., Todaria, N.P. (2009). Fuel wood consumption pattern of tribal communities in cold desert of the Lahaul valley, North-Western Himalaya, India. Biomass and Bioenergy, 33, pp. 1547-1557.

Singh, N. and Sundriyal, R. (2009). Fuelwood, Fodder Consumption and Deficit Pattern in Central Himalayan Village. Nature and Society, 7(4), pp. 85-88.

Wangchuk , S; Siebert, S; Belsky, j. (2014). Fuelwood use and availability in Bhutan: Implications for national policy and local forest management. Human Ecol. 42, pp. 127-135 DOI 10.1007/s10745-013-9634-4.

WECS. 2010. Energy Sector Synopsis Report (2010). Kathmandu: Water and Energy Commission Secretariat.

Sayers, K. and Norconk, M.A. (2008). Himalayan Semnopithecus entellus at Langtang National Park, Nepal: Diet, Activity Patterns, and Resources. Int J Primatol, 29, pp. 509-530. DOI 10.1007/s10764-008-9245-x.

\section{Acknowledgement}

Author highly acknowledges the University Grants Commission of Nepal for providing faculty research grants for conducting fieldwork for the research entitled 'Energy Types and Consumption Pattern of Rural Households and Hotels in the Langtang Valley of Nepal Himalayas.

Note: Views and opinions expressed in this article are the personal views of author. 